\title{
HADIS TENTANG SEBAIK-BAIK MANUSIA
}

\author{
M. Iqbal Nasir \\ La Ode Ismail Ahmad \\ Mahasiswa Program Doktor Pascasarjana UIN Alauddin Makassar \\ iqbalmesja@gmail.com
}

\begin{abstract}
Abstrak: Terdapat hadis mengenai keutamaan orang yang mempelajari al-Qur'an dan mengajarkannya hadis tersebut terdapat dalam beberapa sumber hadis yang terpercaya. Untuk menganalisa hadis tersebut dan menelusuri manfaat hadis tersebut maka sangat menarik untuk dikaji dan ditelaah. Dalam penelitian ini digunakan metode maud $\bar{u}, \bar{i}$ atau kajian tematik dengan mengumpulkan beberapa hadis yang berhubungan dengan tema sebaik-baik manusia adalah yang mempelajari al-Qur'an dan mengajarkannya. Dan jenis penelitian yang digunakan adalah penelitian kualitatif. Penelitian kualitatif digunakan dengan maksud agar penelitian ini benar-benar didapatkan dari hasil penelitian dengan menggunakan cara natural sehingga data yang diperoleh jauh dari aturan atau sifat subyektif peneliti atau kecenderungan penulis dalam melakukan penelitian ini. Dalam penelitian ini dikaji mengenai kualitas hadis sebaik-sebaik manusia adalah yang mempelajari al-Qur'an dan mengajarkannya dan keutamaan orang yang mempelajari al-Qur'an dan mengajarkannya. Dalam mempelajari al-Qur'an perlu diperhatikan kedua aspek yaitu mempelajari al-Qur'an sesuai dengan kaidahkaidah membaca al-Qur'an, dan yang kedua adalah memahami makna al-Qur'an beserta hukum-hukumnya selanjutnya merealisasikannya kedalam kehidupan dan menjadikannya pedoman hidup agar mendapatkan kemulian dunia dan akhirat.
\end{abstract}

\section{Kata Kunci: Al-Qur'an, Hadis, Manusia}

Abstract: There is a hadith about the virtue of people who study the Qur'an and teach it in some sources of trusted hadith. To analyze the hadith and explore the benefits of the hadith, it is very interesting to study and studied. In this study used the method maud $\bar{u}, \bar{i}$ or a thematic study by collecting some hadith related to the theme of the good human is the study of the Qur'an and teach it. And the type of research used is qualitative research. Qualitative research is used with the intention that this research be obtained from the research results by using natural means so that the data obtained far from the rules or the subjective nature of the researcher or the author's tendencies in Do this research. In this study is examined about the quality of hadith as good as human beings is who study the Qur'an and teach it and the virtue of the people who study the Qur'an and teach it. In studying the Qur'an should be considered both aspects of studying the Qur'an in accordance with 
the rules of reading the Qur'an, and the second is to understand the meaning of the Qur'an and its subsequent laws to be made into life And make it a living guideline to get the world and the hereafter.

\section{Keywords: Al-Qur'an, Hadith, Man}

\section{PENDAHULUAN}

Kitab yang diturunkan kepada Muhammad saw adalah al-Qur'an yag dibawa oleh malaikat Jibril kepadanya. Al-Qur'an adalah kalämullāh yang diturunkan sebagai petunjuk sekaligus pedoman bagi umat manusia. Al-Qur'an itu adalah sebuah mukjizat yang tak tertandingi dimanapun dan sampai kapanpun. Di dalam al-Qur'an mukjizat dapat kita kategorikan kepada pembagian, yaitu mukjizat al-qur'an dari segi bahasa, segi ilmiah atau keilmuan, segi tasyri ' atau syariat dan dari segi gaibi.

Sebagai umat muslim, diwajibkan untuk mengetahi kitabnya sendiri yaitu al-Qur'an. Selain itu, umat muslim dituntut untuk mempelajari, memahami alQur'an, bahkan dalam hadis nabi saw. sebaik-baik manusia adalah yang mempelajari al-Qur'an dan mengajarkannya.

Pembinaan manusia atau dengan kata lain pendidikan al-Qur'an terhadap anak didiknya dilakukan secara bersamaan. Satu contoh sederhana adalah sikap al-Qur'an ketika menggambarkan puncak kesucian jiwa yang dialami oleh seorang nabi pada saat menerima wahyu. Al-Qur'an mengaitkan pelaku yang mengalami puncak kesucian tersebut dengan suatu situasi yang bersifat material seperti ketika Musa a.s. menerima wahyu Allah setelah memperkenalkan dirinya (QS Țāhā/20: 17); ketika Nabi Muhammad saw. menerima wahyu oleh Tuhan, ia diingatkan (QS al-Qiyāmah/75: 16); gambaran yang dijelaskan oleh al-Qur'an tentang sikap nabi. QS

Maka dalam tulisan ini, peneliti membahas sebuah hadis nabi tentang sebaik-baik manusia adalah yang mempelajari al-Qur'an dan mengajarkannya. Kajian ini merupakan kajian tematik dalam hadis Nabi saw. dengan rumusan masalah: a) Bagaimana kualitas hadis sebaik-sebaik manusia adalah yang mempelajari al-Qur'an dan mengajarkannya? b) Bagaimana keutamaan orang yang mempelajari al-Qur'an dan mengajarkannya?

\section{METODE PENELITIAN}

Metode yang digunakan dalam penelitian ini adalah metode mauḍ $\bar{u} \bar{i}$. Pendekatan yang digunakan adalah pendekatan pendekatan teologis, pendekatan historis, dan pendekatan sosiologis-antropologis. Teknik pengumpulan dan analisis data dalam penelitian ini adalah dengan dua bentuk data yaitu, pertama, data primer, adalah data yang berasal dari kutub tis'ah (sembilan buku referensi hadis). Kedua, data sekunder, adalah semua data penunjang dari penelitian ini berupa kitab-kitab atau referensi yang berhubungan dengan tema ini. Analisis 
data dilakukan dengan melakukan penelusuran hadis berupa takhrïj hadis dengan kata kunci khairukum man ta'allam al-Qur'ān wa 'allamah.

\section{KUALITAS HADIS SEBAIK-BAIK MANUSIA ADALAH YANG MEMPELAJARI AL-QUR'AN DAN MENGAJARKANNYA}

Dalam pembahasan sebaik-sebaik manusia adalah yang mempelajari alqur'an dan mengajarkannya akan diuraikan sesuai dengan kaedah kasahihan sanad dan matan. Jadi dalam makalah ini akan dibahas kritik sanad terlebih dahulu kemudian masuk dalam pebahasan inti yaitu kritik matan.

\section{MATERI HADIS}

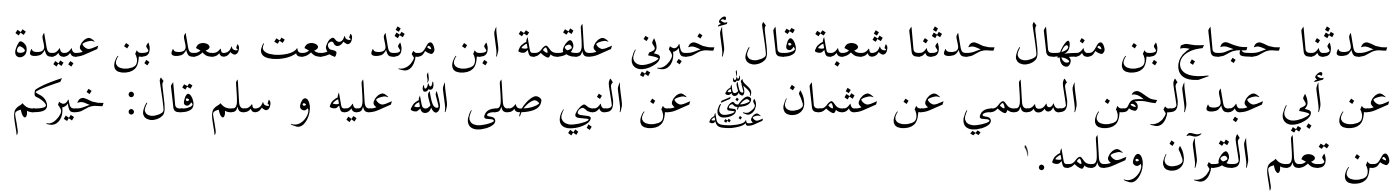

\section{TAKHRĪJ AL-HADĪं}

Ada beberapa mukharrij yang meriwayatkan hadis tentang sebaik-sebaik manusia adalah yang mempelajari al-Qur'an dan mengajarkannya. Beberapa mukharrij yang meriwayatkan hadis tersebut adalah:

a. Al-Bukhārì, kitab Fad̄āil al-Qur'ān, bab Khairukum Man Ta'alam alQur'ān wa 'Allamah, hadis no. 4739, 4740.

b. Al-Turmuzìi, kitab Fad̄àil al-Qur'ān, bab Ta'Tim al-Qur'ān, hadis no. 2907, 2909.

c. Al-Nasāi, kitab Fadāil al-Qur'ān, bab Faụl Man Ta'allam al-Qur'ān, hadis no. 8037.

d. Abū Dāwūd, kitab Al-witr, bab Fì Śawāb Qirāah al-Qur'ān, hadis no. 1454.

e. Aḥmad bin Ḥanbal, kitab Musnad Imām al- 'Asyrah, bab Musnad 'Usmān ibn 'Affäi, hadis no. 412.

f. Al-Dārimī, kitab Fad̄àil al-Qur'ān, bab Khiyārukum Man Ta'alam alQur'ān wa 'Allamah, hadis no. 3337.

\section{STRUKTUR HADIS DAN REDAKSI MATAN HADIS}

a. Al-Bukhārì, kitab Fad̄āil al-Qur'ān, bab khairukum man ta'alam alQur'ānah wa 'allamah, hadis no. 4739 dan 4740.

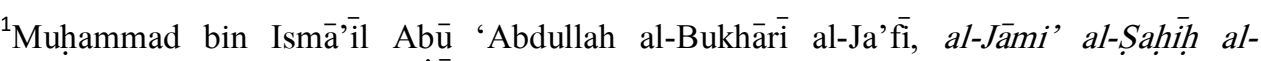
Mukhtasar, Jilid IV(Bairūt: Dār Ibn Kàīir, 1987), h. 1919. 
حدثنا حجاج بن منهال حدثنا شعبة قال أخبرني علقمة ابن مرثد سمعت سعد سعد بن عبيدة

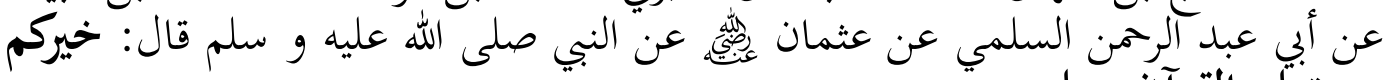

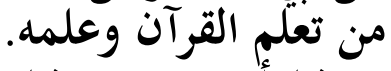

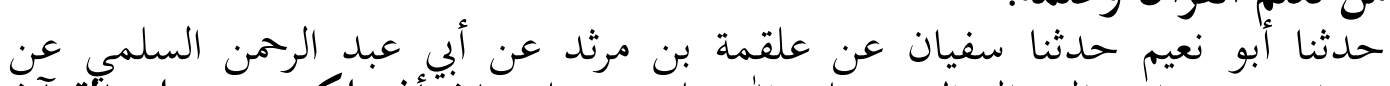

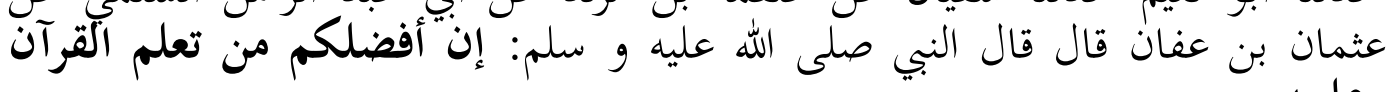
قال وعلمه ؤرأ أبو عبد الرحمن في إمرة عثمان حتى كان الحجاج قال قال وذاك الذي أقعدلي مقعدي هذا.

b. Al-Turmu̇īi, kitab Fadīil al-Qur'ān, bab ta'Tim al-Qur'ān, hadis no. 2907 dan 2909.

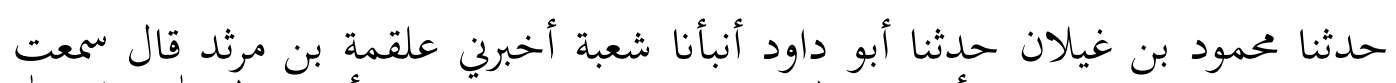

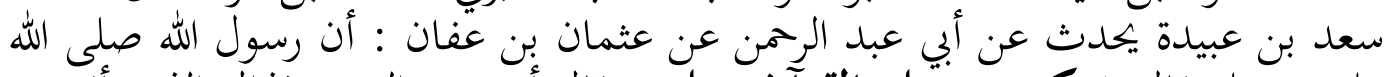

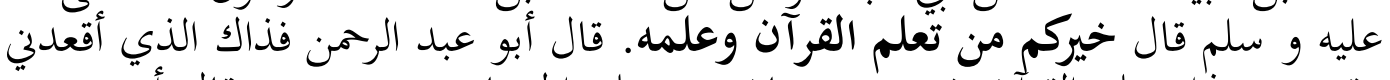

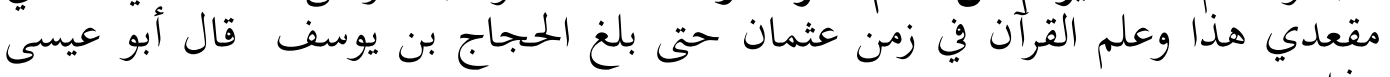

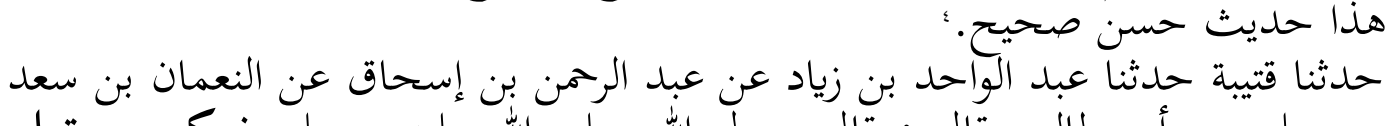

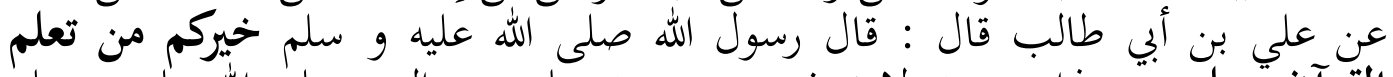

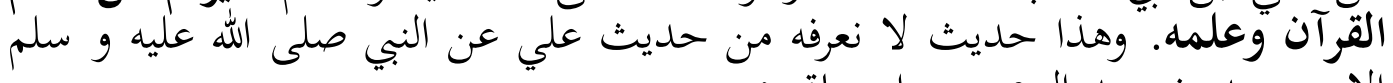

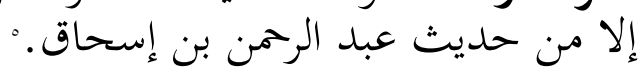

c. Al-Nasāi, kitab Fad̄āil al-Qur'ān, bab faụl man ta'allam al-Qur'ān, hadis no. 8037.

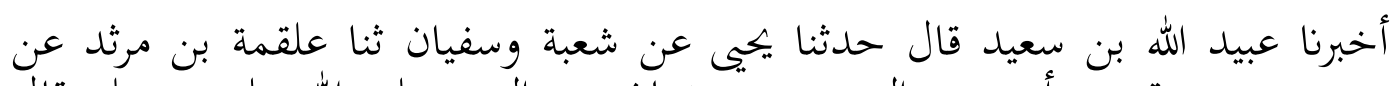

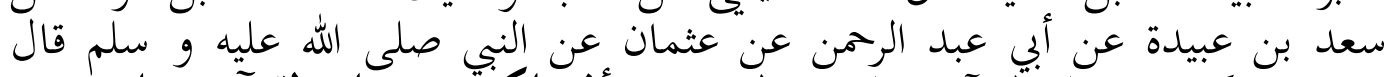

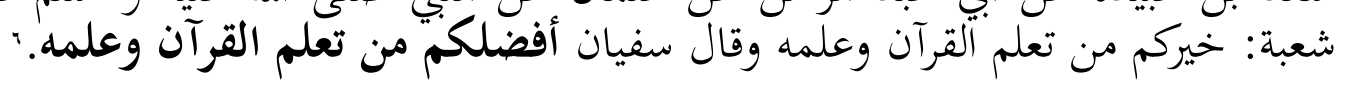

d. Abū Dāwūd, kitab al-witr, bab fì sawāb qirāah al-Qur'ān, hadis no. 1454.

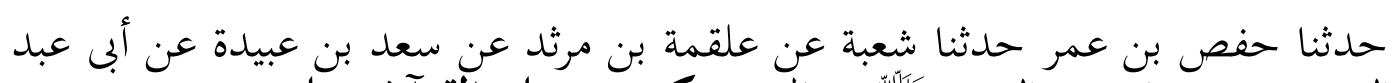

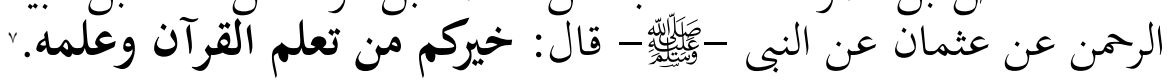

${ }^{2}$ Muhammad bin Ismā' $\bar{i}$ Abū 'Abdullah al-Bukhārī al-Ja' $\bar{i}$, al-Jāmi' al-Sahịh alMukhtasar, h. 1919.

${ }^{3}$ Muhammad bin Ismā' $\bar{i}$ Abū 'Abdullah al-Bukhārī al-Ja' $\bar{i}$, al-Jāmi' al-Sahịh alMukhtasar, h. 1919.

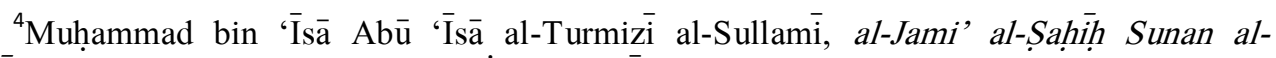
Turmizì, Jilid V (Bairūt: Dār Ihyyā al-Turräs al-‘Arabi) , h. 17r.

${ }^{5}$ Muhammad bin 'İsā Abū 'İsā al-Turmizìi al-Sullamī, al-Jami' al-Sạhịh Sunan alTurmizi, h. 175.

${ }^{6}$ Aḥmad bin Syu'āib Abū 'Abdurraḥmān al-Nasāìi, Sunan al-Nasāì al-Kubrā, Jilid V (Bairūt: Dār al-Kutub al-'Ilmiyyah, 1991), h. 19. 
e. Aḥmad bin Ḥanbal, kitab Musnad Imām al- 'Asyrah, bab Musnad 'Usmān ibn 'Affani, hadis no. 412.

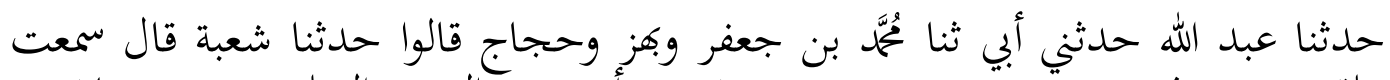

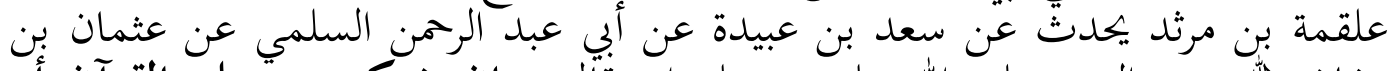

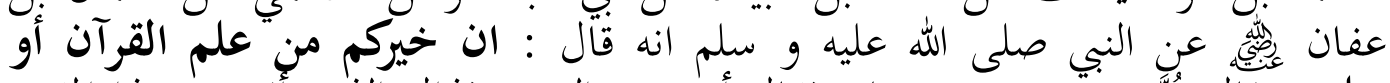

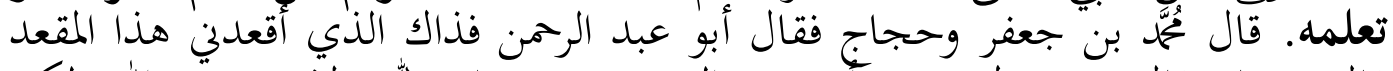

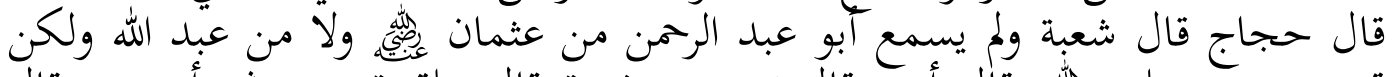

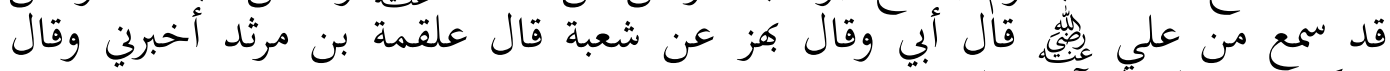
خيركم من تعلم ألقرآن وعلمه.

f. Al-Dārimī, kitab Fad̄āil al-Qur'ān, bab Khiyārukum Man Ta'alam al-Qur'ān wa 'Allamah, hadis no. 3337.

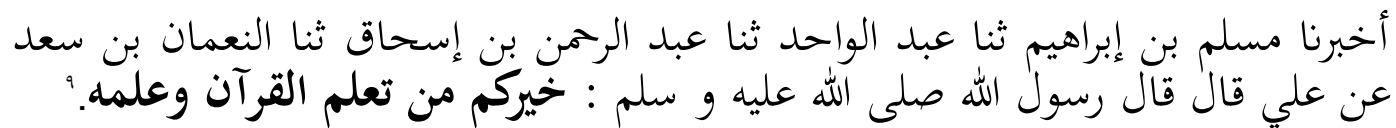
I'TIBAR AL-SANAD

\begin{tabular}{|c|c|c|c|c|c|c|}
\hline No. & $\begin{array}{l}\text { Nama } \\
\text { Mukharrij }\end{array}$ & Sanad & Mutābi' & Syāhid & $\begin{array}{l}\text { Jumlah } \\
\text { Jalur } \\
\text { Sanad }\end{array}$ & $\begin{array}{l}\text { Nama } \\
\text { Sahabat }\end{array}$ \\
\hline 1. & Al-Bukhāri & 2 & 1 & & 2 jalur & $\begin{array}{l}\text { 'Usmān bin } \\
\text { 'Affān. }\end{array}$ \\
\hline 2. & Al-Turmuzì & 2 & & 1 & 2 jalur & 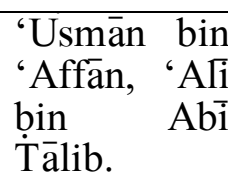 \\
\hline 3. & Al-Nasaì & 1 & 1 & & & $\begin{array}{l}\text { 'Usmān bin } \\
\text { 'Affān. }\end{array}$ \\
\hline 4. & Abū Dāwūd & 1 & & & & $\begin{array}{l}\text { 'Usmān bin } \\
\text { 'Affān. }\end{array}$ \\
\hline 5. & $\begin{array}{l}\text { Ahmad bin } \\
\text { Ḥanbal }\end{array}$ & 1 & 3 & & & $\begin{array}{ll}\text { 'Usmān } & \text { bin } \\
\text { 'Affān, 'Ali } \\
\text { bin } & \text { Abi } \\
\text { Tălib. } & \end{array}$ \\
\hline
\end{tabular}

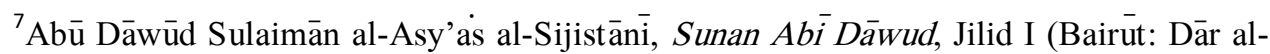
Kutub al-'Arabi), h. $0 \leqslant 3$.

${ }^{8}$ Aḥmad bin Ḥanbal Abū 'Abdullah al-Syaibānī, Musnad al-Imām Ahmad bin Hanbal (alQāhirah: Muassasah Qurtubah), h. 58.

${ }^{9}$ Abdullāh bin 'Abdurraḥmān Abū Muhammad al-Dārimī, Sunan al-Dārimī, Jilid II (Bairüt: Dār al-Kutub al-'Arabīi), h. 5 r^. 


\begin{tabular}{|c|c|c|c|c|c|c|}
\hline 6. & Al-Dārimi & 1 & & & & 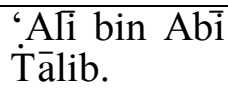 \\
\hline & Jumlah Total & 8 & 5 & 1 & 4 jalur & $\begin{array}{l}2 \text { orang } \\
\text { sahabat }\end{array}$ \\
\hline
\end{tabular}

\section{HASIL DARI KRITIK HADIS SEBAIK-BAIK MANUSIA ADALAH YANG MEMPELAJARI AL-QUR'AN DAN MENGAJARKANNYA}

\section{KRITIK SANAD}

Untuk menentukan kesahihan hadis sebaik-sebaik manusia adalah yang mempelajari al-Qur'an dan mengajarkannya, maka akan dipilih salah satu hadis dari beberapa hadis di atas. Dalam hal ini, yang dipilih adalah hadis yang diriwayatkan oleh Abū Dāwūd dengan perawi sebagai berikut:

1) 'Ussmān bin 'Affān: Periwayat I, sanad terakhir.

2) Abū 'Abdirrahmān: Periwayat II, Sanad V.

3) Sa'd bin 'Ubaidah: Periwayat III, sanad IV.

4) 'Alqamah bin Mursid: Periwayat IV, sanad III.

5) Syu'bah: Periwayat V, sanad II.

6) Hafṣ bin 'Umar: Periwayat VI, sanad I.

7) Abū Dāwūd: Periwayat VII, Mukharrij.

Akan diuraikan satu persatu perawi dari hadis Abū Dāwūd sebagai berikut:

\section{1) Abū Dāwūd}

a) Nama lengkapnya adalah Sulaimān bin al-Asy'as bin Isḥāq bin Basyīi bin Syaddād Abū Dāwūd al-Sijistānī al-Hāfiz.

b) Gurunya adalah Abū Salamah al-Tabüzakī, Abū al-Walìd al-

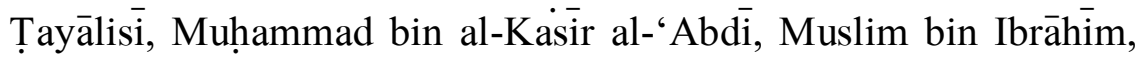
Abū 'Umar al-Haw ḍ̂i, Abū Taubah al-Ḥalibì, Hafṣ bin 'Umar dan lainnya.

c) Muridnya adalah Abū 'Alī Muhammad bin Ahmad bin 'Amr alLu'luī, Abu al-Ṭayyib Aḥmad bin Ibrāhīm ibn 'Abdurraḥmān alAsynāni.

d) Penilaian ulama ulama terhadap dirinya, Abū Bakr al-Hilāl berkata Abū Dāwūd adalah imam yang terdepan di zamannya, pandai dalam mentakhrij beberapa disiplin ilmu, seorang yang wara'. Aḥmad bin Ạ̣mad bin Yāsin al-Hurawì berkata ia merupakan salah seorang yang menguasai hadis beserta ilmunya serta 'ilalnya 
dan sanadnya pada derajat tertinggi disertai dengan ketaatan beribadah, penyucian diri, budi pekerti dan wara. ${ }^{10}$

2) Ḣafṣ bin 'Umar

a) Nama lengkapnya adalah Hafṣ bin 'Umar bin al-Hāris bin Sakhbarah al-Azdì al-Namrì Abū 'Umar al-Hawḍ̂i al-Baṣri ibn alNamr bin Gaimān.

b) Gurunya adalah Syu'bah, Ibrāhīm bin Sa'd, Hisyām bin 'Abdullah, Hamām, Yazīd bin Ibrāhīm, Ḥamād ibn Zaìd, Abū Hilāl al-Rāsibī, Khālid bin 'Abdillah, Muhammad bin Rāsyid al-Makhūi $\bar{i}$, Abū 'Uwānah dan lainnya.

c) Muridnya adalah al-Bukhārī, Abū Dāwūd, al-Nasāì.

d) Adapun komentar ulama tentang Hafș, Aḥmad berkata: $\dot{S} a b t u$ sabtin, mutqin. Ibn al-Madini: Ahlu Bașrah sepakat akan keadilan Abū 'Umar. 'Ubaidullah ibn Jarīr bin Jublah: Mutqin. Ya'qūb bin Syaibah: Ia termasuk dari golongan Mutasabbitīn. Abū Hạatim: Șadūq, mutqin, 'arab fașīh. Al-'Abbās al-Daūrì: Awsaq, ạ̣san h̆adisan, asyhar. Al-Dāraquṭīi: Siqah. ${ }^{11}$

3) Syu'bah

a) Nama lengkapnya adalah Syu'bah bin al-Hajjāj bin al-Warad al'Atakì al-Azdí.

b) Gurunya adalah Ubbān bin Tuglub, Ibrāhīm bin 'Amir bin Mas'ūd, Ibrāhīm bin Muhammd al-Muntasyir, Ibrāhīm bin Muslim al-Hijri, Ibrāhīm bin Muhājir, 'Alqamah bin Mursid, dan lainnya.

c) Muridnya adalah Ayyūb, al-A'masy dan lainnya.

d) Adapun komentar ulama hadis terhadapnya sebagia berikut: Aḥmad bin Hanbal: Syu'bah lebih șabit di dalam hukum dari ala'masy. Hammād bin Salamah: Jika kalian ingin hadis maka bertanyalah pada Syu'bah. Al-Syafi'ì: Kalau bukan Syu'bah maka tidak akan diketahui hadis di Iraq. Yazid bin Zarì': Syu'bah adalah orang yang paling jujur dalam hadis. Al-Nadir bin Syumail: Aku tidak pernah melihat orang yang sangat mengasihi orang miskin. ${ }^{12}$

${ }^{10}$ Ibn Hajar al-'Asqalānī, Tahżì al-Tahżìb, Jilid IV, h. 149- 151.

${ }^{11}$ Ibn Ḥajar al-‘Asqalānī, Tahżib al-Tahzìib, Jilid II, h. 350.

${ }^{12}$ Ibn Hẹar al-'Asqalānī, Tahżíb al-Tahżìb, Jilid IV, h. 301-302. 
4) 'Alqamah bin Mursid

a) Nama lengkapnya adalah 'Alqamah bin Mursid al-Ḥaḍramī abū al-Hāaris al-Kūfi.

b) Gurunya adalah Sa'd bin 'Ubaidah, Zur bin Hubaisy, Tạariq bin Syihāb, al-Mustaurad bin al-Aḥnaf, Sulaimān bin Buraidah, Ruzaīn bin Sulaimān, Hậṣ bin 'Ubaidillah bin Anas, 'Abdurraḥmān bin Sābt, al-Qāsim bin Mukhaimarah dan lainnya.

c) Di antara muridnya adalah Syu'bah, al-Sauri.

d) Adapun komentar ulama hadis terhadapnya sebagai berikut, Abū Hạatim berkata: Saliḥ al-Hadìs. Al-Nasāi: Śiqah. Ibn Hibbān: Śqqah. Ya'qūb bin Sufyān: $\dot{S}$ iqah. ${ }^{13}$

5) Sa'd bin'Ubaidah

a) Nama lengkapnya adalah Sa'd bin'Ubaidah al-Sullami Abū Damrah al-Küfi.

b) Gurunya adalah al-Mugīrah bin Syu'bah, Ibn 'Umar, al-Barrā' bin 'Azib, Ḥibbān bin 'Ațiyyah, al-Mustaurad ibn al-Ạ̣naf, Abū 'Abdurraḥmān al-Sullami.

c) Di antara muridnya adalah al-A'masy dan Mansūr.

d) Berikut komentar ahli hadis terhadapnya: Ibn Mu'in berkata:

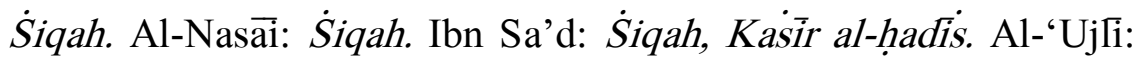
Seorang täbi' yang siqah. ${ }^{14}$

6) $\mathrm{Abu}$ 'Abdirraḥmān

a. Nama lengkapnya adalah 'Abdullāh bin Hubaib bin Rubai'ah Abū 'Abdurrahmān al-Sullamī al-Kūfí al-Qārì.

b. Gurunya adalah 'Umar, 'Úsmān, 'Alì, Sa'd, Khālid bin al-Wālid, Ibn Mas'ūd, Ḥuzaīfah, Abū Mūsāa al-Asy`arī, Abū al-Dardā', Abū Hurairah r.a.

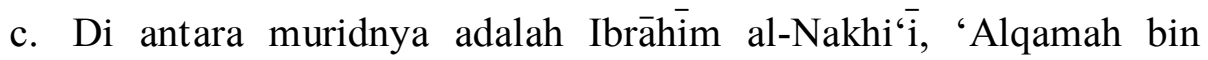
Mursid.

d. Adapun komentar para ahli hadis terhadapnya sebagai berikut: Al'Ajli berkatā: Orang Kūfah, dari golongan tabi'īn, dan siqah. Abū Dāwūd: ia buta. Al-Nasāi: Śiqah. Hajjāj bin Muhammad dari

${ }^{13}$ Ibn Hajar al-'Asqalāni, Tahżīb al-Tahzīib, Jilid VII, h. 246.

${ }^{14}$ Ibn Hajar al-‘Asqalāni, Tahżìb al-Tahżìb, Jilid III, h. 415. 
Syu'bah: Ia tidak pernah mendengar Ibn Mas'ūd, 'Úsmān, tetapi ia mendengar hadis dari 'Ali. ${ }^{15}$

Pernyataan Syu'bah ini bertentangan dengan struktur sanad dalam hadis yang diriwayatkan oleh Abū Dāwūd dimana Abū 'Abdurraḥmān tidak pernah mendengar hadis dari 'Úsmān. Tetapi kenyataan dalam hadis ini Abū 'Abdurraḥmān meriwayatkannya langsung dari 'Úsmān. Jika diteliti hadis ini bermasalah karena ada kritik sanad dari ulama jarh dan ta'dil. Tetapi jika dilihat dari hadis yang diriwayatkan oleh al-Bukhari, alNasāi hadis ini bisa naik derajatnya menjadi sạ̣ih li zātih karena adanya hadis sahih yang mendukungnya. Dan bisa jadi, yang dimaksud Hajjāj bin Muḥammad adalah 'Abdurraḥmān bin Ishạā, sebagaimana pernyataan alTurmizì bahwa ia tidak mengetahui hadis dari 'Ali bin Abi Tàlib kecuali melalui periwayatan 'Abdurraḥmān bin Isḥāq.

7) 'Üsmān bin 'Affān

a. Nama lengkapnya adalah 'Úsmān bin 'Affān bin Abì al-'Ạs bin Umayyah bin 'Abd Syams bin 'Abd Manāf al-Qurasyì.

b. Gurunya adalah Rasulullah Muhammad saw, Abū Bakr, 'Umar.

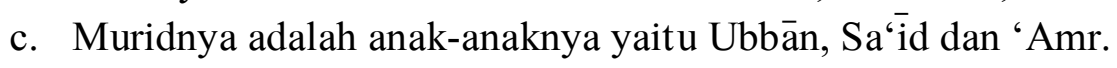

d. Adapun komentar para perawi hadis terhadapnya yaitu: Ibn 'Abd al-Bārr berkata: Orang yang pertama hijrah ke tanah Habasyah. 'Ali bin Abì Tālib: 'Úsmān adalah orang yang sangat suka menyambung silaturahmi di antara kami. Ibn Sïrin: 'Úsmān menghidupkan malam dengan sebuah raka' at kemudian membaca al-Qur'an di dalamnya. 'Āisyah: Mereka membunuhnya padahal ia sangat suka menyambung silturahmi dan paling bertaqwa kepada Tuhannya. $^{16}$

Hadis yang diriwayatkan Abū Dāwūd sanadnya semuanya bersambung tidak ada yang jatuh. Kemudian keadaan perawinya tidak ada yang cacat, baik dari segi keadilannya maupun kedabitannya, tidak ada syadz dan tidak ada illat. Dan dalam rentetan sanad dalam hadis Abū Dāwūd memiliki sanad yang kuat, seperti siqah, awsaq, șadūq, mutqin, dari awal sanad hingga akhir sanadnya. Jadi dalam sanad Abū Dāwūd semua dapat dipegangi dan kebanyakan siqah dan mutqin, dan tidak ada kecacatan dalam diri perawi.

${ }^{15}$ Ibn Hạar al-‘Asqalānī, Tahżīb al-Tahżīb, Jilid V, h. 161.

${ }^{16}$ Ibn Hajar al-‘Asqalāni, Tahzīib al-Tahżīb, Jilid VII, h. 128. 
Setelah menelusuri hadis yang diriwayatkan Abū Dāwūd ini, semua perawi pertama hingga terakhir tidak memiliki cacat dan semuanya siqah yaitu adil dan ḍăbit. Adapun yang diriwayatkan oleh Hajjaj bin Muhammad dari Syu'bah mengenai Abū 'Abdurraḥmān, kesahihannya bisa ditopang dan didukung oleh hadis sahih li żătih yang lain.

\section{KRITIK MATAN}

Sebelumnya sudah diteliti beberapa hadis yang diriwayatkan dengan beberapa jalur sanad dan sudah diuraikan sebuah hadis yang diriwayatkan oleh Abū Dāwūd beserta kualitas sanad-sanadnya satu persatu maka dapat disimpulkan bahwa sanadnya muttașil adil dan dabit, serta kecuali satu jalur dari riwayat Abū Dāwud yang derajatnya naik dari derajat hasan ke hasan lizātih. ${ }^{17}$

Jika dilihat dari sisi matan hadis yaitu hadis

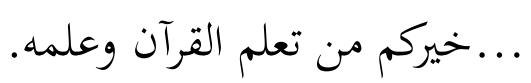

Semua redaksi sama kecuali jalur Abū Na'īm dari Sufyān dari 'Alqamah. Adapun redaksi hadisnya sebagai berikut:

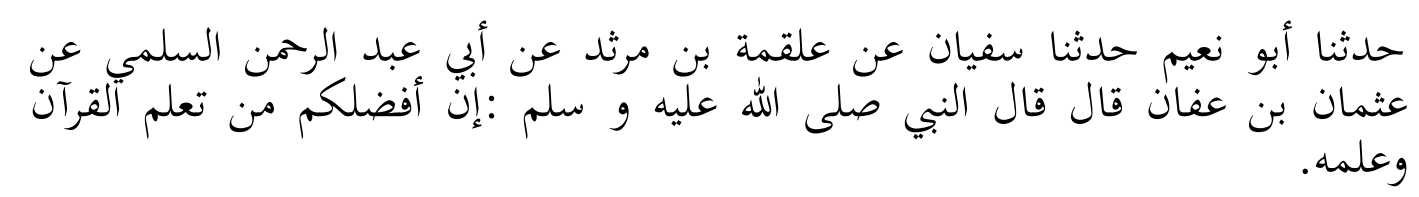

Dalam redaksi hadis di atas terdapat kata إن أفضلكم yang berbeda dengan redaksi hadis lainnya. Ini bisa dikarenakan terjadi periwayatan hadis bil ma'nā karena jalur yang dipakai sama yaitu dari 'Alqamah hingga kepada 'Úsmān ra. Periwayatan bil ma'nā ini bertujuan untuk saling melengkapi riwayat dan penjelasan hadis. $^{18}$

Riwayat Sufyān memang agak berbeda dengan riwayat yang lainnya. Sufyān bernama lengkap Sufyān bin Sa'ìd bin Masrūq Abū 'Abdullah al-Küfi. Ia terkenal dengan kesiqahannya. Mengenai hal ini ada beberapa komentar para perawi hadis mengenai Sufyān antara lain;

1. Syu'bah, Abū 'Uyaīnah, Abū 'Așim, dan Ibn Mu'īn dan lainnya mengatakan bahwa Sufyān merupakan amīr al-mu'minin.

2. Wakī' berkata dari Sa'ìd, Sufyān lebih hafiz bagiku.

${ }^{17}$ Maḥmūd Ṭaḥhān, Taisīr Mușțalah al-Ḥadis (Cet. X; Maktabah al-Ma’ārif, 2004), h. 50.

${ }^{18}$ Darsul S. Puyu, Kuantitas dan Kualitas Hadis-Hadis yang Diklaim Misogini (Cet. I; Makassar: Alauddin University Press, 2014), h. 115. 
3. Al-Dauri berkata, aku melihat yahyā bin Ma'in tidak mendahulukan seseorang di zamannya kecuali Sufyān dalam bidang fikih, hadis, kezuhudan dan semua hal.

4. Ibn al-Madinī, aku tidak mengetahui Sufyān melakukan taṣhīif. ${ }^{19}$

Ibnu Hajar juga mempertegas bahwa Sufyān merupakan siqāt ahl al$K{ }_{\text {ufah. }}{ }^{20}$ Dalam redaksi hadis ini walaupun secara lafaz berbeda tetapi secara makna sama yaitu anjuran untuk mempelajari al-Qur'an dan mengamalkannya. Di lihat dari segi bahasa hadis ini tidak bertentangan karena dalam bahasa arab lafaz al-ta'kid sering digunakan dalam bahasa arab. Contohnya dalam ilmu nahwu ada bab taukid untuk menguatkan ucapan. Ada juga bab Inna wa akahwätuhā yang sudah disusun ulama. Pembahasan isim tafọil digunakan untuk membandingkan sesuatu atau barang dengan tujuan ingin memberikan nilai dalam barang tersebut. Jadi secara teori bahasa tidak ada pertentangan antara lafaz إن أفضلكم dengan ilmu bahasa arab.

Dalam redaksi beberapa hadis di terdahulu yang diriwayat oleh enam perawi yaitu al-Bukhārì, Muslim, al-Turmuzìi, Abū Dāwūd, Aḥmad bin Hanbal dan al-Dārimi, ditemukan beberapa redaksi yaitu:

1.

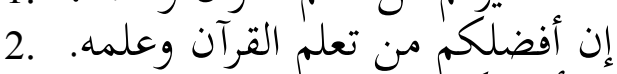

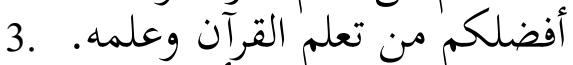

4. ان خيركم من علم القرآن أو تعلم آن وعلمه.

Dari empat redaksi di atas, terdapat dua redaksi yaitu kata khair dan kata afdal. Dalam penjelasan redaksi khairukum dikatakan bahwa khair al-asyā' każa', tidak dimaksudkan bahwa khaìr jamī' al-asyyā', (kebaikan dari semua benda) dari semua bentuk dan dari setiap hal dan individual, akan tetapi, dilihat dari sebuah keadaan, bukan keadaan yang lain atau yang semisalnya. ${ }^{21}$ Terkadang seseorang mengatakan bahwa khaî̀ al-asyä' każa', tidak dimaksudkan bahwa kebaikannya pada semua benda, akan tetapi itulah sebaik-baik perbuatan pada keadaan tertentu bukan pada keadaan yang lain. ${ }^{22}$

Dari penjelasan tersebut, dipahami bahwa:

${ }^{19}$ Ibn Hajar al-‘Asqalānī, Tahżìb al-Tahżìb, Jilid IV, h. 101.

${ }^{20}$ Lihat Ahmad bin 'Ali bin Hajar Abū al-Faḍl al-'Asqalānì al-Syāfi’’’, Fatḥ al-Bārī (Bayrüt: Dār al-Ma’rifah, Jilid IX, 1379), h. 77.

${ }^{21}$ Abu Zakariyyā'- Yạyā bin Syaraf al-Nawawī, al-Minhāj Syarh Sạhịh Muslim bin alHajjāj, jilid II (Cet. II; Bairūt: Dār Ihyā' Turrä́s al-'Arǎ̌i’, 1392 H), h. 77.

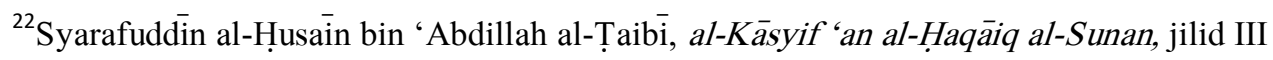
(Cet. I; alRiyāḍ: al-Nazzār Muṣtafā al-Bāz, 1997, h. 867. 
1. Kata khaìr dan kata khairunnās adalah sama atau dalam bahasa arab disebut badal (pengganti). Jadi khairukum adalah pengganti dari kata khairukum atau khaìr al-asyā'?

2. Adanya persamaan antara kata khairukum dan afdalukum adalah semakna, yaitu khairukum semakna dengan kata afdalukum dari segi bahasa arab.

3. Penambahan kata inna dalam redaksi hadis sebaik-baik manusia adalah yang mempelajari al-Qur'an dan mengajarkannya adalah perbedaan matan hadis yang bisa saja dipengaruhi oleh sejarah historis turunnya hadis atau hadis ini diriwayatkan beberapa kali atau hadis ini diriwayatkan bi alma'nā.

Dilihat dari pendakatan ilmu al-Qur'an hadis ini sangat sejalan dengan alQur'an Allah berfirman QS al-Isrä/17: 82.

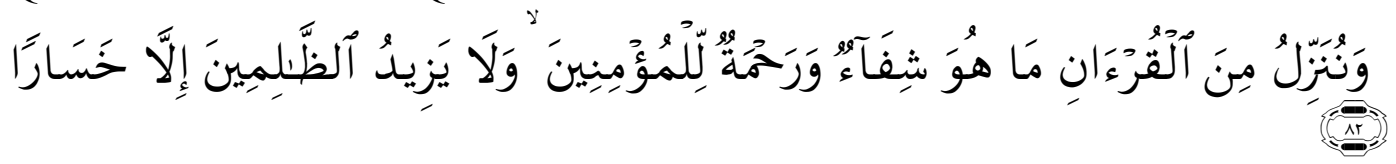

Terjemahnya:

Dan Kami turunkan dari Al Quran suatu yang menjadi penawar dan rahmat bagi orang-orang yang beriman dan Al Quran itu tidaklah menambah kepada orang-orang yang zalim selain kerugian.

Al-Qur'an sebagai petunjuk di dalamnya terdapat pelajaran, ilmu tauhid, ilmu hukum, manfaat, petunjuk, keselamatan dan seterusnya. Oleh karena itu wajib kita mempelajari dan merenungi tujuan dari al-Qur'an itu. Dengan tujuan dari diturunkannya al-Qur'an maka hadis ini sebagai penjelas dan sebagai pendorong agar manusia mempelajari al-Qur'an. Dan hadis di atas sangat sejalan dengan hadis Abū Dāwūd tentang mempelajari al-Qur'an dan mengajarkannya.

Selanjutnya, hadis yang diriwayatkan oleh Abū Dāwūd tidak bertentangan dengan hadis lainnya. Karena ada beberapa hadis yang sejalan makna hadis ini. Antara lain:

1. Al-Bukhārì, kitab Fad̄āil al-Qur'ān, bab khairukum man ta'alam alQur'ānah wa 'allamah, hadis no. 4739, 4740.

2. Al-Turmuzìi, kitab Fadäil al-Qur'ān, bab ta'Tim al-Qur'ān, hadis no. 2907, 2909.

3. Al-Nasāi, kitab Fad̄āil al-Qur'ān, bab fậl man ta'allam al-Qur'ān, hadis no. 8037. 
Dalam hadis di atas tidak ditemukan hadis yang mardud atau daif seperti maudu'. matruk, munkar, mudraj, maqlub, dan yang lainnya. Karena sanad dan matan terbebas dari isqat sanad atau munqati' begitu juga syaz dan 'illah.

Dalam pendekatan akal sehat, hadis di atas tidak bertentangan dengan rasio atau akal sehat. Karena al-Qur'an merupakan kitab yang benar dan selalu ingin memberikan jalan keluar bagi manusia untuk selamat dunia begitu juga akhirat.

\section{NATIJAH HADIS SEBAIK-BAIK MANUSIA ADALAH YANG MEMPELAJARI AL-QUR'AN DAN MENGAJARKANNYA DILIHAT DARI SISI MAQBUL DAN MARDUD.}

Jika seorang perriwayat lebih kuat kritik positifnya (ta'dil) maka hadis yang diriwayatkan berpeluang sahih. Namun apabila kritikan negatif (tajrịh) lebih menonjil maka riwayat hadisnya akan menjadi $\underset{\text { da }}{ } \bar{i} \mathrm{i} f$ (palsu). ${ }^{23}$

Berdasarkan penelitian hadis Abū Dāwūd di atas dan melalui kaedah kesahihan sanad dan matan hadis di atas berkualitas sahih li zatih karena telah mendapatkan legitimasi dari beberapa sanad melalui beberapa jalur terlebih lagi memiliki sanad yang disepakati oleh al-Bukhari yang merupakan kitab yang paling sahih. Dan hadis hadis Abū Dāwūd bisa dijadikan hujjah dan dapat diamalkan. Șubḥi Șālih menjelaskab bahwa sahih li zātih yaitu hadis yang mencakup sifat-sifat qabul. Sahih li gairih karena tidak memenuhi syarat-syarat diterimanya hadis seperti hadis hasan, jika ada yang menguatkannya maka ia bisa naik ke derajat sahih. ${ }^{24}$

\section{KEUTAMAAN ORANG YANG MEMPELAJARI AL-QUR'AN DAN MENGAJARKANNYA}

\section{PENGERTIAN AL-QUR'AN}

قر أ- يقر أ- قرز عا- قراءة(qara'a-yaqra'u-qar'an-qirā'atan-wa-qur'ānan). ${ }^{25}$ Kata qara'a dan derivasinya secara umum terdapat sebanyak 88 kali dan pengelompokan jenis dari kata tersebut didapatkan sebanyak 30 kali. $^{26}$

\footnotetext{
${ }^{23}$ Darsul S. Puyu, Kuantitas dan Kualitas Hadis-Hadis yang Diklaim Misogini, h. 63.

${ }^{24}$ Ṣubḥhì al-Ṣāliḥ, 'Ulum al-Hadis wa Muștaluḥuh (Cet. IV;Dar 'Ilm li al-Malāyīn), h. 146.

${ }^{25}$ Muhammad bin Ya'qūb al-Fairūzābādi, al-Qāmūs al-Mụ̣ịt, jilid I, h. 62.

${ }^{26}$ Muhammad Zak̄i Muhammad Khiḍr, Mu’jam Kalimāt al-Qur’ān al-Karīm, jilid XXIII (Ā̇ār, 2005), h. 5 .
} 
Dikatan al-Qur'an karena Allah swt. mengumpulkan surahnya Allah berfirman bagi Kami pengumpulannya dan Qur' annya yaitu pengumpulannya dan qira'atnya. ${ }^{27}$ Dan juga penamaan al-Qur'an karena di dalamnya terkumpul hukum-hukum dan kisah-kisah dan selainnya. ${ }^{28}$

Al-Qur'an menurut istilah adalah:

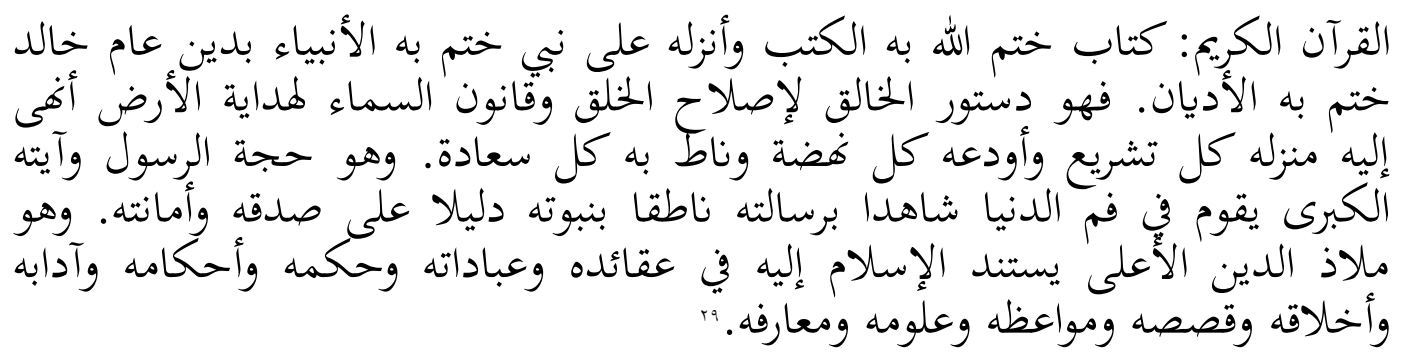

Artinya:

Al-Qur'an al-Karim adalah kitab yang merupakan kitab terakhir dan diturunkan kepada nabi yang terakhir dengan agama yang universal kekal penutup semua agama. Al-Qur'an merupakan peraturan Tuhan untuk kebaikan ciptaanNya dan undang-undang langit untuk memberikan hidayah kepada dunia, kedudukan al-Qur'an menyempurnakan dunia dengan semua syariat, memberikan dunia semua kekuatan dan semua kebahagian. Al-Qur'an merupakan dalil rasul dan ayatnya yang besar yang berperan di dunia, sebagai saksi bagi risalahnya, berbicara atas nama kenabiannya, bukti atas kebenaran dan amanahnya. Al-Qur'an merupakan pelindung agama yang tinggi dimana Islam bersandar kepadanya dalama akidah-akidahnya, ibadah-inadahnya, hikmah-hikmahnya, hukumhukumnya, adab-adabnya, akhlak-akhlaknya, kisah-kisahnya, petunjukpetunjuknya, ilmu-ilmunya, dan makrifat-makrifatnya.

Adapun kemukjizatan al-Qur'an, al-Suyuṭi dalam kitab al-Itqān menjelaskan bahwa:

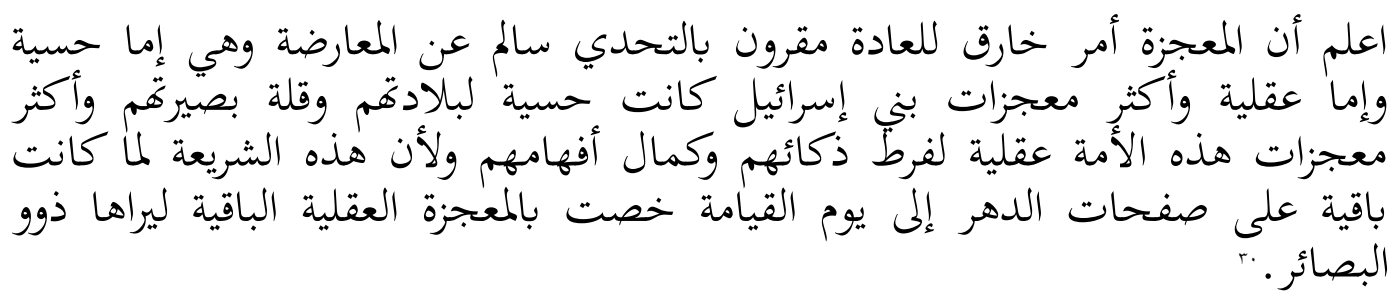

${ }^{27}$ Muhammad bin Mukrim bin MAnzūr al-Afiq $\bar{i}$ alMiṣri, Lisān al-'Arab (Cet. I; Bairūt: Dār Ṣādir), h. 128.

${ }^{28}$ Abū al-Ḥusaīn Aḥmad bin Fāris bin Zakariyyā, Mu’jam Maqāyīs al-Lugah, jilid V (Dār al-Fikr, 1979), h. 79.

${ }^{29}$ Muhammad 'Abd al-'Azīim al-Zurqānī, Manāhil al-'Irfān fī 'Ulüm al-Qur'ān (Cet. III; Mațba'ah 'Īsā al-Bānì al-Ḥalabìi, 1367), h. jl.

30، Abdurraḥmān bin al-Kamāl al-Suyūṭ̂̀, al-Itqān fi 'Ulūm al-Qur'ān, jilid II, h. 311. 


\section{Artinya:}

Ketahuilah bahwa mukjizat adalah sesuatu yang luar biasa disertai dengan penantangan (al-Qur'an), bebas dari kekurangan, dan mukjizat terbagi atas dua, mukjizat yang ditangkap dengan pancaindra dan mukjizat yang bersifat rasional. Dan kebanyakan mukjizat Bani Israil berupa mukjizat yang ditangkap dengan pancaindra karena pengetahuan mereka yang belum maju, dan kebanyakan mukjizat umat ini (umat Muhamma) berupa mukjizat yang berupa rasional karena keistimewaan ilmu mereka dan kesempurnaan pemahaman mereka, dan karena syariat ini kekal sepanjang masa hingga hari kiamat maka dikhususkan untuk mukjizat yang bersifat rasional kekal agar orang yang berilmu dapat melihatnya.

Al-Qur'an merupakan bukti bahwa Nabi Muhammad saw. adalah benarbenar seorang nabi dan rasul yang menyampaikan agama Islam, sebagai pemberi berita gembira dan peringatan, menyampaikan isi al-Qur'an sebagai kalam Tuhan sehingga manusia dapat bahagia, mendapatkan ketenangan, keselamatan dunia dan akhirat. Al-Qur'an merupakan pedoman, di dalamnya terdapat nilai-nilai ketauhidan, syariat dan hakikat agama, hidup, dan akhirat yang terkumpul dalam sebuah mushaf al-Qur'an.

\section{KEABSAHAN AL-QUR'AN}

Al-Qur'ān al-Karim adalah kitab yang oleh rasul saw. dinyatakan sebagai tali Allah yang terulur dari langit ke bumi, di dalamnya terdapat berita tentang umat masa lalu, dan kabar tentang situasi masa dating. Siapa yang berpegang pada petunjuknya dia tidak akan sesat. Kitab suci ini juga memperkenalkan dirinya sebagai hudan li al-nās (petunjuk bagi seluruh umat manusia), sekaligus menantang manusia dan jin untuk menyusun semacam al-Qur'an. Dari sini kitab suci kita berfungsi sebagai mukjizat (bukti kebenaran), sekaligus kebenaran itu sendiri. $^{31}$

Berbicara mengenai bukti al-Qur'an dapat diketahui melalui tiga hal.

a. Keindahan, keserasian dan keseimbangan kata-katanya. Kata yaüm yang berarti hari, dalam bentuk tunggalnya terulang sebanyak 365 kali (ini sama dengan satu tahun), dalam bentuk jamak diulangi sebanyak 30 kali (ini sama dengan satu bulan). Sementara itu kata syahr yang berarti bulan, hanya terdapat 12 kali. Kata panas dan dingin masingmasing diulangi sebanyak 4 kali, sementara dunia dan akhirat, hidup dan mati, setan dan malaikat, dan masih banyak yang lainnya, semuanya seimbang dalam jumlah yang serasi dengan tujuannya dan indah kedengarannya.

${ }^{31}$ M. Quraish Shihab, Secercah Cahaya Ilahi: Hidup Bersama al-Qur'an (Cet. I; Bandung: Mizan, 2000), h. 13. 
b. Pemberitaan gaib yang diungkapkannya. Awal surah al-Rūm menegaskan kekalahan Romawi oleh Persia pada 614 itu benar adanya, tepat pada saat kegembiraan kaum Muslim memenangkan perang Badar pada 622. Pemberitaan tentang keselamatan badan Fir'aun yang tenggelam di Laut Merah 3.200 tahun yang lalu, baru terbukti setelah muminya (badannya yang diawetkan) ditemukan oleh Loret di Wadi al-Muluk Thaba, Mesir, pada tahun 1896 dan dibuka pembalutnya oleh Eliot Smith 8 Juli 1907.

c. Isyarat-isyarat ilmiahnya sungguh mengagumkan ilmuan masa kini, apalagi yang menyampaikannya adalah seorang ummí yang tidak pandai membaca dan menulis serta hidup dilingkungan masyarakat terkebelakang. Bukti kebenaran mukjizat rasul-rasul Allah bersifat suprarasional. Hanya Muhammad yang dating membawa bukti rasional. Ketika masyarakatnya meminta bukti selainnya. Sungguh disayangkan bahwa tidak sedikit umat Islam dewasa ini bukan hanya tak pandai membaca kitab sucinya, tetapi juga tidak memfungsikannya, kecuali sebagai penangkal bahaya dan pembawa manfaat dengan cara-cara irasional. ${ }^{32}$

Sebuah pemahaman adalah menemukan kejelasan dari seluruh ayat yang berkaitan dengan al-Qur'an, sebab al-Qur'an memuat penyebutan sifat-sifat Allah, perbuatanNya, cerita tentang keadaan para nabi, cerita tentang keadaan orang-orang yang mendustakan mereka, serta keadaan para pendusta itu sendir bagaimana mereka dihancurkan. Al-Qur'an juga menyebutkan perintah-perintah dan larangan-laranganNya serta menceritakan surga dan neraka. ${ }^{33}$

Dalam memahami kemukjizatan al-Qur'an dibutuhkan tiga poin penting.

a. Melalui kepribadian Nabi Muhammad saw. Begitu juga seputar kehidupan keseharian beliau, terutama akhlak dan budi pekertinya sebagai orang yang membawa tugas sebagai seorang nabi dan pemberi berita gembira dan peringatan melalui al-Qur'an atau wahyu yang dibawanya.

b. Kondisi masyarakat saat turunnya al-Qur'an. Dalam hal ini perkembangan ilmu pengetahuan pada masa turunnya al-Qur'an dan

${ }^{32}$ M. Quraish Shihab, Lentera Hati: Kisah dan Hikmah Kehidupan (Cet. XXIV; Bandung: Mizan, 2002), 28-29.

33، Abdul Ḥāim Maḥmud, al-Qur'ān fi Syahr al-Qur'ān, terj. Irwan Raihan, Abu Fahmi, Tadarus Kehidupan di Bulan al-Qur'an (Cet. II; Yogyakarta: Madani Pustaka Hikmah, 2001), h. 102. 
kemampuan ilmiah masyarakat arab pada waktu itu dan manusia pada umumnya.

c. Masa dan cara kehadiran al-Qur'an. Hal ini berkaitan dengan turunnya al-Qur'an kepada Nabi Muhammad saw. diluar kehendaknya dan kehadirannya secara tiba-tiba. ${ }^{34}$

\section{MAKSUD MEMPELAJARI DAN MENGAJARKAN AL-QUR'AN}

Teori dalam belajar al-Qur'an sama dengan teori mengajarkan al-Qur'an. Maksud mempelajari dan mengajarkan al-Qur'an di sini adalah mempelajari dan mengajarkan cara membaca al-Qur'an yaitu tiläwah, kemudian mempelajari dan mengajarkan cara menghafal atau tahfiż, mempelajari dan mengajarkan tafsirnya, serta mempelajari dan mengajarkan yang berkaitan dengan ilmu al-Qur'an atau 'ulüm al-Qur'a.n.

Membaca al-Qur'an dapat dibagi menjadi dua bagian yaitu:

a. Membaca secara lafziyyah, yaitu membaca al-Qur'an pada umumnya, seperti memperhatikan tajwidnya, makhrajnya, dan semua kaidahkaidah dalam membaca al-Qur'an.

b. Membaca secara hukmiyyah, menerapkan hukum-hukum al-Qur'an dengan cara melaksanakan perintah al-Qur'an dan menjauhi larangannya atau yang disebut beramal dengan al-Qur'an. ${ }^{35}$

Mempelajari dan mengajarkan al-Qur'an juga dapat dipahami secara umum sebagaimana rasulullah mengajarkan para sahabatnya mengenai al-Qur'an dan diterapkan bebebrapa metode dalam mempelajari dan mengajarkan alQur'an.

Untuk menciptakan suasana kondusif dan menyenangkan dalam mengajar para sahabatnya, rasulullah menggunakan bermacam metode. Hal itu dilakukan untuk menghindarkan kebosanan dan kejenuhan siswa. Di antara metode yang diterapkan rasulullah adalah: a) metode ceramah, b) dialog, misalnya dialog antara rasulullah dengan Mu'àz bin Jabal ketika Mu'àz akan diutus sebagai Qậ̣ $\bar{i}$ di negeri Yaman, c) diskusi atau Tanya jawab, sering sahabat bertanya kepada rasulullah tentang suatu hukum dan rasulullah menjawabnya. d) metode diskusi, misalnya diskusi antara rasulullah dan para sahabatnya tentang hukuman yang akan diberikan kepada tawanan perang Badar, e) metode demonstrasi, misalnya

\footnotetext{
${ }^{34}$ Lihat M. Quraisy Shihab, Mukjizat al-Qur'an: Ditinjau dari Aspek Kebahasaan, Isyarat Ilmiah, dan Pemberitaan Gaib(Cet. IX; Bandung: Mizan, 2001), h. 64-74.

${ }^{35}$ Sa'd bin 'Alì bin Wahf al-Qahțāni, 'Azamat al-Qur'ān wa Ta'żìmuh wa Aśaruh fi al-Nufüs fi Dau’ al-Kitāb wa al-Sunnah, h. 33.
} 
hadis rasulullah tentang salat, f) metode eksperimen, metode sosiodrama, dan bermain peranan. Selanjutnya metode akhlak diseampaikan nabi dengan membacakan ayat-ayat al-Qur'an yang berisi kisah-kisah umat dahulu kala, supaya diambil pengajaran dan i'tibär dari kisah itu. Orang yang taat dan patuh mengikuti rasulullah, akan mendapatkan kebahagiaan dan orang yang durhaka mendapat siksa. Di samping dengan metode kisah, pendidikan akhlak juga dilakukan dengan menggunakan metode penegasan dan uswah hasanah. Misalnya dengan menjelaskan kriteria orang-orang munafik dan akibatnya, dan mempersaudarakan kaum Ansar dengan Muhajirin. Metode-metode akhlak yang diterapkan rasululllah sangat berbekas di dalam pola tingkah laku para sahabat. Hal ini dapat dilihat dari kondisi umat saat itu yang betul-betul patuh dan taat pada perintah rasulullah saw. Persaudaraan di antara kaum Muhajirin dan Ansar terbina dengan rapat kokoh dan penuh kasih saying. ${ }^{36}$

\section{MEMPELAJARI AL-QUR'AN DAN MENGAJARKANNYA DALAM HADIS NABI SERTA KEUTAMAANNYA}

Dalam hadis rasulullah saw. terdapat beberapa hadis yang menganjurkan untuk mempelajari dan mengajarkan al-Qur'an. Adapun hadis tersebut sebagai berikut:

Hadis dari Abū Umāmah al-Bāhīili.

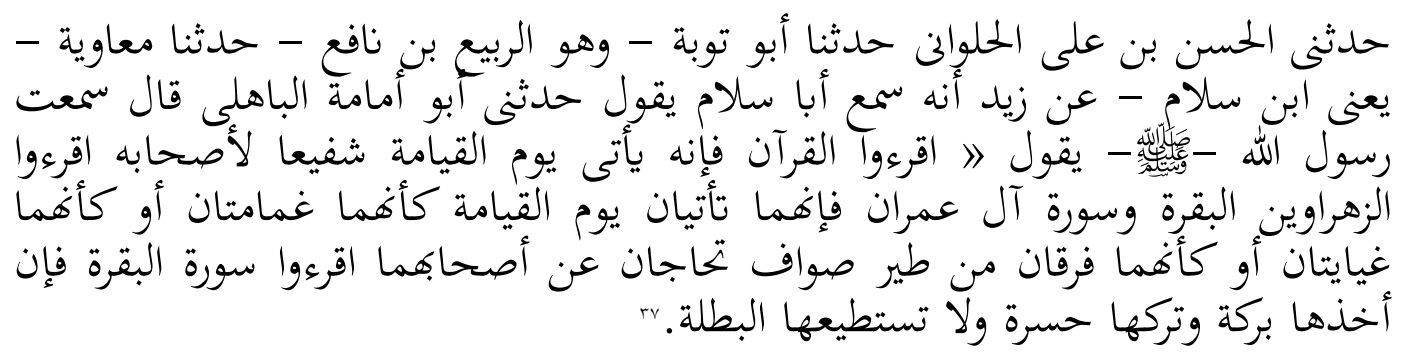

Artinya:

Bacalah al-Qur'an karena al-Qur'an akan dating pada hari kiamat nanti sebagai syafi' (pemberi syafaat) bagi yang membacanya. Bacalah azZahrowain (dua surat cahaya) yaitu surah al-Baqarah dan Ali 'Imran karena keduanya datang pada hari kiamat nanti seperti dua awan atau seperti dua cahaya sinar matahari atau seperti dua ekor burung yang membentangkan sayapnya (bersambung satu dengan yang lainnya), keduanya akan menjadi pembela bagi yang rajin membaca dua surat tersebut. Bacalah pula surat al-Baqarah. Mengambil surat tersebut adalah

\footnotetext{
${ }^{36}$ Samsul Nizar, Sejarah Pendidikan Islam: Menelusuri Jejak Sejarah Pendidikan Era Rasulullah sampai Indonesia (Cet. V; Jakarta: Kencana Prenada Media Group, 2013), h. 16-17.

${ }^{37}$ Abū al-Ḥusaīn Muslim _bin al-Ḥajjāj bin Muslim al-Qusyairī al-Nīsābūrì, al-Jāmi' alSahịh, Jilid II (Bairūt: Dārul al-Baīt), h. 197.
} 
suatu keberkahan dan meninggalkannya akan mendapat penyesalan. Para tukang sihir tidak mungkin menghafalnya.

Dari Abū Mūsā al-Asy’arī.

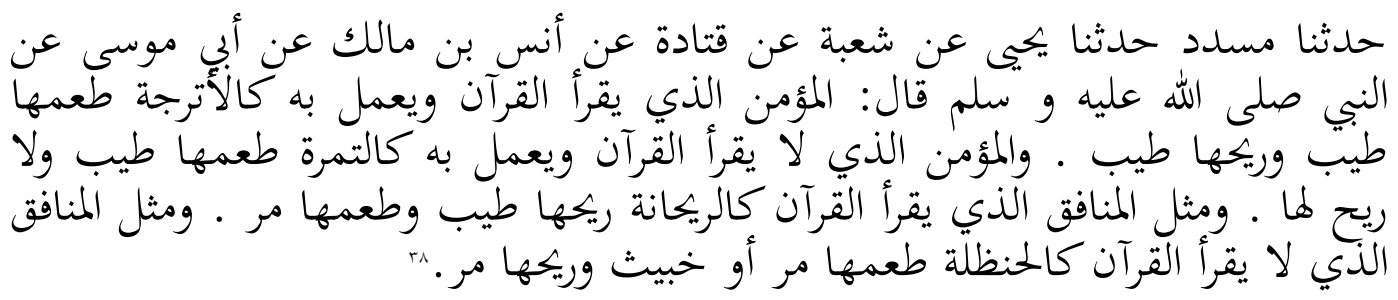

Artinya:

Permisalan orang yang membaca al-Qur'an dan mengamalkannya adalah bagaikan buah utrujah, rasa dan baunya enak. Orang mukmin yang tidak membaca al-Qur'an dan mengamalkannya adalah bagaikan buah kurma, rasanya enak namun tidak beraroma. Orang munafik yang membaca alQur'an adalah bagaikan royhanah, baunya menyenangkan namun rasanya pahit. Dan orang munafik yang tidak membaca al-Qur'an bagaikan hanzholah, rasa dan baunya pahit dan tidak enak.

Dari ‘Abdullāh bin Mas‘ūd

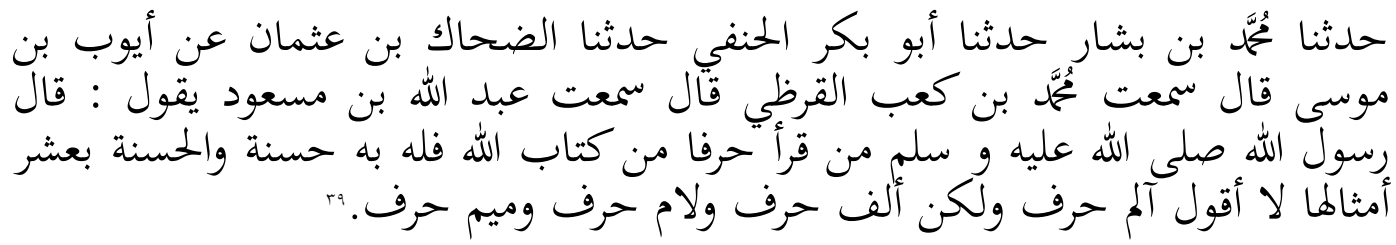

Artinya:

Barang siapa yang membaca satu huruf dari al-Qur'an, maka baginya satu kebaikan. Satu kebaikan akan menjadi sepuluh kali lipat. Aku tidak mengatakan alif laam mim itu satu huruf, melainkan alif satu huruf, lam satu huruf dan mim satu huruf.

Dari ‘Abdullāh bin ‘Amr.

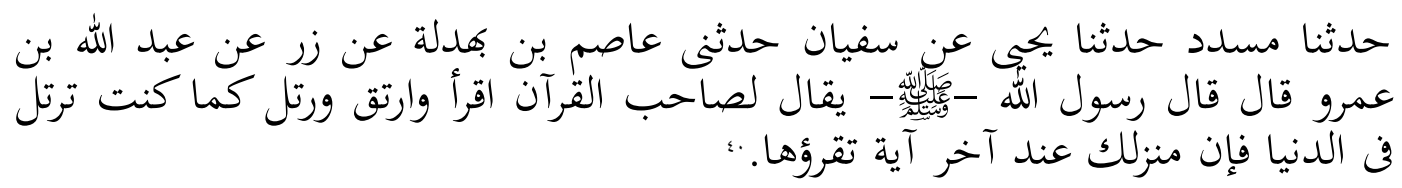

Artinya:

Dikatakan kepada orang yang membaca (menghafalkan) al-Qur' an nanti: Bacalah dan naiklah serta tartillah sebagaimana engkau di dunia

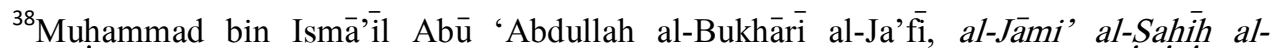
Mukhtasar, Jilid IV(Bairūt: Dār Ibn Kàsīr, 1987), h. 1928.

${ }^{39}$ Muhammad bin 'İsā Abū 'İsā al-Turmizì al-Sullamī, al-Jami' al-Sahịh Sunan alTurmizī, Jilid V (Bairūt: Dār Ihyā al-Turräs al-‘Arabī), h. 175.

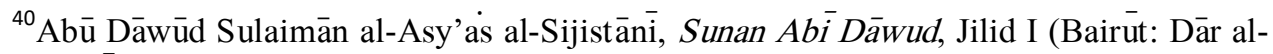
Kutub al-'Arabi), h. $0 \leqslant \mathrm{~V}$. 
mentartilnya. Karena kedudukanmu adalah pada akhir ayat yang engkau baca (hafal).

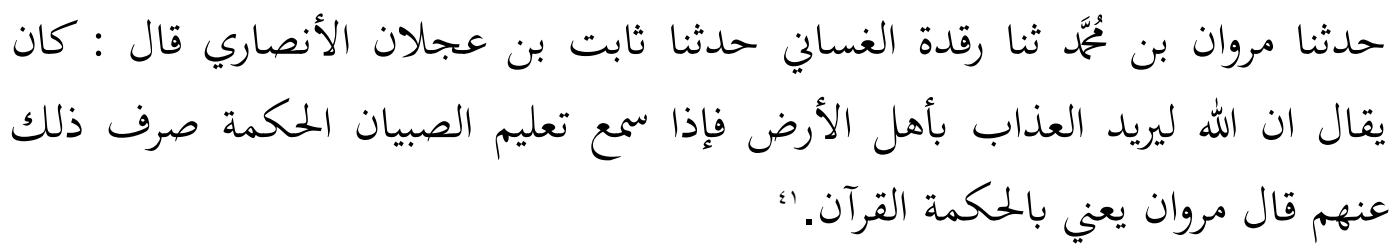

Artinya:

Telah menceritakan kepada kami Marwan bin Muhammad telah menceritakan kepada kami Rifdah al-Ghassani telah menceritakan kepada kami Tsabit bin 'Ajlan al-Anshari ia berkata: dikatakan; sesungguhnya Allah berkehendak untuk memberikan azab kepada penduduk bumi, namun ketika dia mendengarkan beberapa anak kecil mempelajari alHikmah, dia memalingkan azab tersebut dari mereka. Marwan berkata; Yang dimaksud dengan al-Hikmah adalah al-Qur'an.

Hadis dari Ibn 'Abbās disebutkan bahwa:

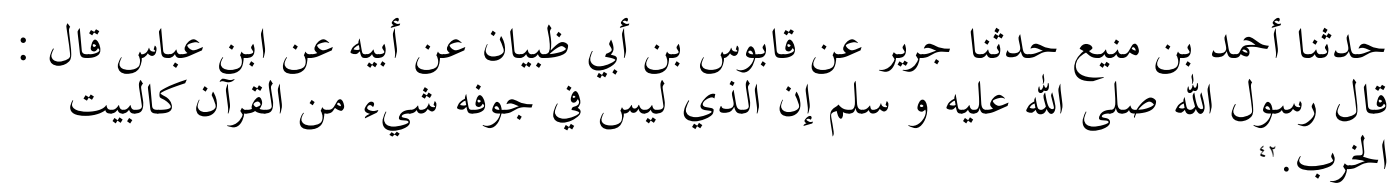

Artinya:

Telah menceritakan kepada kami Ahmad bin Mani' telah menceritakan kepada kami Jarir dari Qabus bin Abu Dzabyan dari Ayahnya dari Ibnu Abbas ia berkata: Rasulullah saw. bersabda: "Sesungguhnya orang yang di dalam dirinya tidak ada sedikit pun al-Qur'an ibarat rumah yang runtuh.” Abu Isa berkata; Hadis ini hasan shahih.

Hadis dari 'Abdullāh bin 'Amr

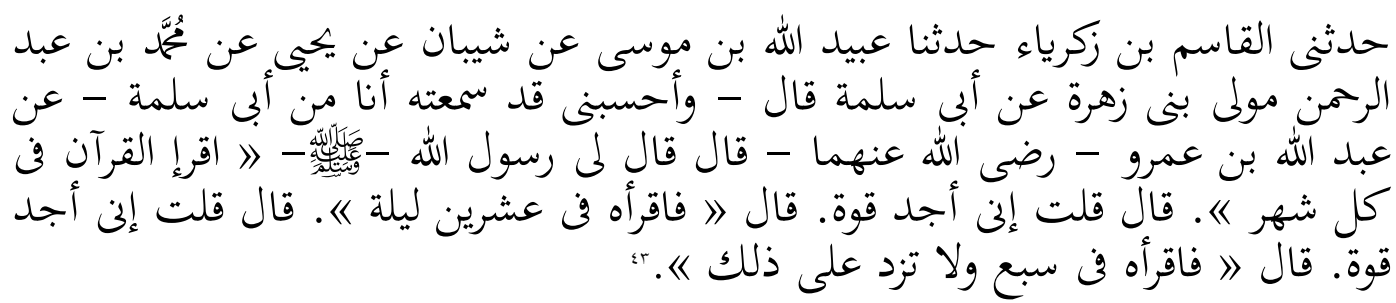

Artinya:

Dari 'Abdullah bin 'Amr r.a. rasulullah berkata kepadaku: Bacalah alQur'an setiap bulan! Aku berkata kepadanya bahwa bahwa aku memiliki kesanggupan untuk membacanya. Rasulullah berkata: Maka bacalah dalam 20 hari. Aku berkata kepadanya bahwa bahwa aku memiliki

41، Abdullāh bin 'Abdurraḥmān Abū Muhammad al-Dārimī, Sunan al-Dārimīi , Jilid II (Bairüt: Dār al-Kutub al-'Arabī), h.or.

${ }^{42}$ Muhammad bin 'İsā Abū 'İsā al-Turmizìi al-Sullamī, al-Jami' al-Sahịh Sunan al-

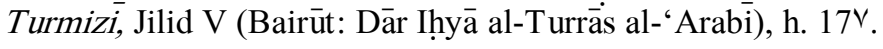

${ }^{43}$ Abū al-Husaīn Muslim bin al-Hajajāj bin Muslim al-Qusyairī al-Nīsābūrì, al-Jāmi' alSahịh, Jilid III (Bairūt: Dārul al-Baìt), h. 163. 
kesanggupan untuk membacanya. Rasulullah berkata: Maka bacalah dalam sepekan dan jangan kurang dari itu.

Dari Zurāah r.a.

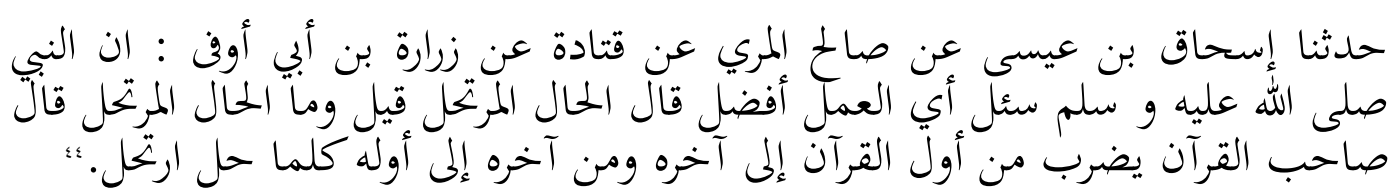

Artinya:

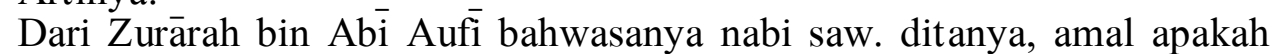
yang paling afdal? Nabi berkata: keadaan orang murtahil, dikakatan bagaimana keadaan orang murtahir? Nabi berkata: Pembaca al-Qur'an, ia membaca dari awal al-Qur'an hingga akhirnya dan dari akhirnya hingga awalnya setiap kali ia khatam ia melanjutkannya lagi.

Dari Jābir bin ‘Abdillāh

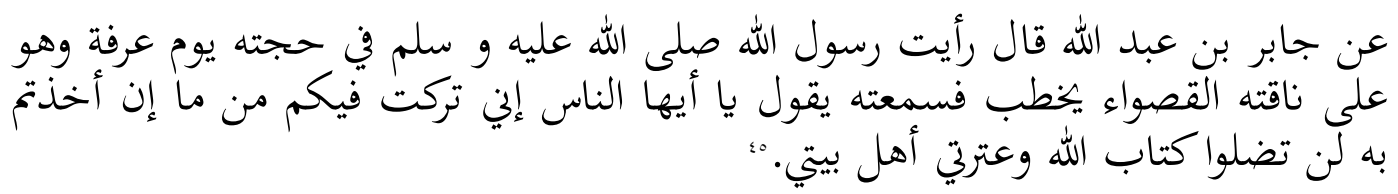

Artinya:

Dari Jābir bin 'Abdillah berkata: Aku melihat rasulullah saw. dalam hajinya hari arafah di atas unta betina berkhutbah, aku mendengarnya berkata: Wahai manusia aku meninggalkan di antara kalian, jika kalian mengambilnya maka kalian tidak akan tersesat, yaitu al-Qur'an dan keluargaku ahli bait.

Dari beberapa hadis di atas, maka dapat pula ditarik beberapa keutamaan orang yang mempelajari dan mengajarkan al-Qur'an sebagai berikut:

1. Orang yang mempelajari al-Qur'an dan mengajarkannya, kelak di akhirat al-Qur'an akan menjadi penolongnya dan menjadi pelindungnya sebagai wujud dari amalnya di dunia.

2. Orang yang membaca al-Qur'an dan mengajarkannya atau secara umum mengamalkannya akan tercermin dari dalam dirinya ajaran al-Qur'an sehingga mempengaruhi setiap tingkah lakunya.

3. Orang yang selalu membaca dan mengajarkan al-Qur'an akan mendapatkan pahala yang berlipat ganda setiap ia membaca huruf dalam al-Qur'an.

${ }^{44}$ Abdullāh bin 'Abdurraḥmān Abū Muhammad al-Dārimī, Sunan al-Dārimīi , Jilid II (Bairūt: Dār al-Kutub al-'Arabī), h. 560.

${ }^{45}$ Muhammad bin 'İsā Abū 'Isāa al-Turmizì al-Sullamī, al-Jami' al-Sahịh Sunan alTurmizi, Jilid III (Bairūt: Dār Ihyāa al-Turräs al-‘Arabī), h. 226. 
4. Ayat al-Qur'an jika dipelajari dan diamalkan akan memberikan derajat kepada pembacanya sesuai ayat terakhir yang ia baca di dunia.

5. Mengajarkan al-Qur'an pada anak kecil dapat menghindarkan bala atau azab dunia.

6. Pengibaratan orang yang tidak pernah membaca dan mempelajari alQur'an bagaikan rumah yang runtuh atau tidak memiliki manfaat.

7. Mempelajari al-Qur'an dan mengajarkannya merupakan sebuah usaha dalam mendekatkan diri kepada Tuhan karena al-Qur'an merupakan kalam Tuhan yang bisa langsung dibaca oleh siapa pun, serta dengan mengajarkan al-Qur'an dapat meningkatkan wawasan seorang tenaga pengajar karen ia sudah berenang dalam samudera al-Qur'an.

8. Al-Qur'an sebagai guru dan pembimbing bagi manusia sehingga tidak melangkah menuju kesesatan dan menjadi sarana ibadah bagi kaum muslimin ketika membaca, mengajar serta mengamalkan al-Qur'an.

Selanjutnya mempelajari dan mengajarkan al-Qur'an memiliki fungsi dan tujuan. Adapun fungsi dan tujuan al-Qur'an adalah:

1. Untuk membersihkan akal dan menyucikan jiwa dari segala bentuk syirik serta menetapkan keyakinan tentang keesaan yang sempurna bagi Tuhan, kayakinan yang tidak semata-mata sebagai suatu konsep teologis, tetapi falsafah hidup dan kehidupan umat manusia.

2. Untuk mengajarkan kemanusian yang adil dan beradab, yakni umat manusia merupakan suatu umat yang seharusnya dapat bekerja sama dalam pengabdian kepada Allah dan pelaksanaan tugas kekhalifahan.

3. Untuk menciptakan persatuan dan kesatuan, bukan saja antar suku atau bangsa, tetapi kesatuan lam semesta, kesatuan kehidupan dunia dan akhirat, natural dan supranatural, kesatuan ilmu, iman, dan rasio, keatuan kebenaran, kesatuan kepribadian manusia, kesatuan kemerdekaan dan determinamisme, kesatuan sosial, politik, dan ekonomi, dan kesemuanya berada di bawah satu keesaan, yaitu keesaan Allah swt.

4. Untuk mengajak manusia berpikir dan bekerja sama dalam bidang kehidupan bermasyarakat dan bernegara melalui musyawarah dan mufakat yang dipimpin oleh hikmat kebijaksanaan.

5. Untuk membasmi kemiskinan material dan spiritual, kebodohan, penyakit , dan penderitaan hidup, serta pemerasan manusia atas manusia, dalam bidan sosial, ekonomi, politik, dan juga agama.

6. Untuk memadukan kebenaran dan keadilan dengan rahmat dan kasih saying, dengan menjadikan keadilan sosial sebagai landasan pokok kehidupan masyarakat. 
7. Untuk memberi jalan tengah antara falsafah monopoli kapitalisme dengan falsafah kolektif komonisme, menciptakan ummatan wasatan yang menyeru kepada kebaikan dan mencegah kemungkaran.

8. Untuk menekankan peranan ilmu dan teknologi, guna menciptakan satu peradaban yang sejalan dengan jati diri manusia, dengan panduan Nur Ilahi. $^{46}$

Mengajarkan al-Qur'an yaitu yaitu mengajari orang lain cara cara membaca al-Qur'an yang benar berdasarkan hokum tajwid. Sekiranya mengajarkan ilmu-ilmu lain secara umum atau menyampaikan sebagian ilmu yang dimiliki kepada orang lain adalah perbuatan mulia dan mendapatkan pahala dari Allah swt, dan tentunya mengajarkan al-Qur'an lebih utama.

Namun, orang yang belajar al-Qur'an adalah sebaik-baik orang muslim dan mengajarkan al-Qur'an kepada orang lain juga sebaik-baik orang muslim, tentu akan lebih baik dan utama lagi jika orang tersebut menggabungkan keduanya. Maksudnya orang tersebut belajar cara membaca al-Qur'an sekaligus mengajarkan kepada orang lain apa yang telah dipelajarinya.

\section{KESIMPULAN}

1. Hadis tentang sebaik-baik manusia adalah yang mempelajari al-Qur'an dan mengajarkannya dan melalui kaedah kesahihan sanad dan matan hadis tersebut berkualitas sahih li zatih karena telah mendapatkan legitimasi dari beberapa sanad melalui beberapa jalur terlebih lagi memiliki sanad yang disepakati oleh al-Bukhari yang merupakan kitab yang paling sahih. Dan begitu juga hadis hadis Abū Dāwūd yang diteliti dalam penelitian ini dapat dijadikan hujjah dan dapat diamalkan.

2. Setelah mengkaji beberapa hadis yang berhubungan dengan tema yang dipilih yaitu sebaik-baik manusia adalah yang mempelajari al-Qur'an dan mengajarkannya, maka dari hasil pengumpulan hadis dengan system tematik maka dapat diambil sebagai pelajaran adalah a) manusia dianjurkan untuk senantiasa membaca, mempelajari serta mengamalkan al-Qur'an dalam kehidupan sehari-hari. b) manusia diperintahkan mempelajari serta mengamalkan al-Qur'an sejak dini. c) menunjukkan betapa agung dan mulianya al-Qur'an dibandingkan dengan kitab-kitab lainnya sebelum al-Qur'an. Al-Qur'an sebagai pengertian umum adalah gabungan antara pendidikan spiritual yang nilai legalitasnya yang tinggi dan penggabungan antara rasionalitas manusia dalam menyikapi

${ }^{46}$ M. Quraish Shihab, Wawasan al-Qur'an: Tafsir Maudhu'I atas Pelbagai Persoalan Umat (Cet. VIII; Bandung: Mizan, 1998), h. 12-13. 
kehidupan mereka baik secara individual maupun secara universal. Sehingga dengan mempelajari al-Qur'an dan mengajarkannya akan tercipta kerukunan bermasyarakat karena memahami nilai-nilai yang terkandung dalam al-Qur'an dan yang mempelajarinya akan merasakan ketenangan rohani sehingga dalam melihat dunia dan alur perjalanan kehidupannya akan dilalui dengan kemantapan hati dan kepuasan jiwa sehingga terhindar dari masalah-masalah dunia yang merupakan cobaan bagi manusia.

\section{DAFTAR PUSTAKA}

\section{Al-Qur'ān al-Karìm}

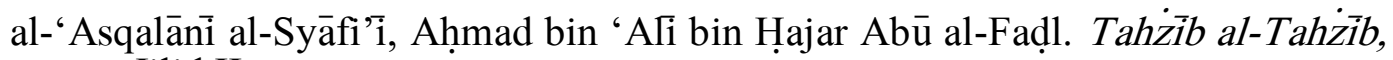
Jilid II.

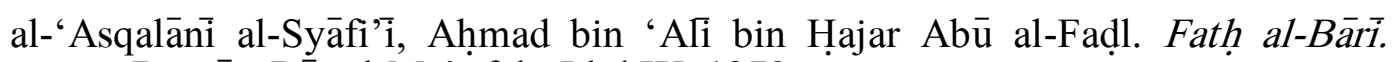
Bayrüt: Dār al-Ma'rifah. Jilid IX, 1379.

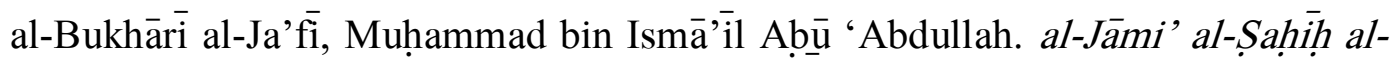
Mukhtasar, Jilid IV(Bairūt: Dār Ibn Kasir, 1987), h. 1919.

al-Dārimī, Abdullāh bin 'Abdurraḥmān Abū Muhammad. Sunan al-Dārimī . Jilid II. Bairut: Dār al-Kutub al-'Arabi.

al-Fairūzābādi, Muhammad bin Ya'qūb. al-Qāmūs al-Muḥịt, jilid I.

al-Nasāì, Ahmmad bin Syu'aīb Abū 'Abdurraḥmān. Sunan al-Nasāì al-Kubrā, Jilid V. Bairūt: Dār al-Kutub al-'Ilmiyyah. 1991.

al-Qahțāni, Sa'd bin 'Alì bin Wahf. 'Azamat al-Qur'ān wa Ta'żimuh wa Asisaruh fi al-Nufüs fi Dau' al-Kitāb wa al-Sunnah.

al-Qusyairī al-Nisābūri, Abū al-Husāin Muslim _bin al-Hajajāj bin Muslim alJāmi' al-Sahịh, Jilid II. Bairūt: Dārul al-Baìt.

al-Ṣāliḥ, Șubḥhī. 'Ulum al-Ḥadis wa Muṣtaluḥuh. Cet. IV;Dar 'Ilm li al-Malāāin. al-Sijistānī, Abū Dāwūd Sulaimān al-Asy'às. Sunan Abī Dāwud. Jilid I. Bairūt: Dār al-Kutub al-'Arabi.

al-Suyūți, 'Abdurrạ̣mān bin al-Kamāl al-Itqān fi 'Ulūm al-Qur'ān, jilid II.

al-Syaibānī, Aḥmad bin Hanbal Abū 'Abdullah. Musnad al-Imām Aḥmad bin Hanbal. al-Qāhirah: Muassasah Qurtubah.

al-Turmizī al-Sullamī, Muhammad bin 'İsā Abū 'İsā. al-Jami' al-Sahịh Sunan alTurmizi. Jilid V. Bairūt: Dār Ihyā al-Turràs al-'Arabì.

al-Zurqānī, Muhammad 'A Cet. III; Maṭba'ah 'İsā al-Bāni al-Ḥalabì, 1367.

bin Manzūur al-Afíqi alMișri, Muhammad bin Mukrim. Lisān al-'Arab. Cet. I; Bairūt: Dār Șādir.

Fāris bin Zakariyyāa, Abū al-Ḥusāin Ahmad bin. Mu'jam Maqāyīs al-Lugah, jilid V. Dār al-Fikr, 1979. 
Kementerian Agama RI, Al-Qur'an Al-Karim dan Terjemahnya . t.c., Surabaya: Halim. 2013.

Mahmud, 'Abdul Halìm. al-Qur'ān fi Syahr al-Qur'ān, terj. Irwan Raihan, Abu Fahmi, Tadarus Kehidupan di Bulan al-Qur'an . Cet. II; Yogyakarta: Madani Pustaka Hikmah. 2001.

Muhammad Khịdr, Muhammad Zakī. Mu'jam Kalimāt al-Qur'ān al-Karīm, jilid XXIII. Äzār, 2005.

Muslim al-Qusyairī_al-Nisābūrî, Abū al-Husaīn Muslim bin al-Hajjāj bin alJämi’. al-Saḥịh, Jilid III. Bairūt: Dārul al-Bait.

Nizar, Samsul Sejarah Pendidikan Islam: Menelusuri Jejak Sejarah Pendidikan Era Rasulullah sampai Indonesia. (Cet. V; Jakarta: Kencana Prenada Media Group, 2013.

S. Puyu, Darsul. Kuantitas dan Kualitas Hadis-Hadis yang Diklaim Misogini. Cet. I; Makassar: Alauddin University Press. 2014.

Shihab, M. Quraish. Lentera Hati: Kisah dan Hikmah Kehidupan. Cet. XXIV; Bandung: Mizan. 2002.

Shihab, M. Quraish. Secercah Cahaya Ilahi: Hidup Bersama al-Qur'an. Cet. I; Bandung: Mizan, 2000.

Shihab, M. Quraish. Wawasan al-Qur'an: Tafsir Maudhu'I atas Pelbagai Persoalan Umat. Cet. VIII; Bandung: Mizan. 1998.

Shihab, M. Quraisy. Mukjizat al-Qur'an: Ditinjau dari Aspek Kebahasaan, Isyarat Ilmiah, dan Pemberitaan Gaib. Cet. IX; Bandung: Mizan, 2001.

Tahḥ̄ān, Mạ̣mūd. Taisīr Muṣtalaḥ al-Hadìis. Cet. X; Maktabah al-Ma'ārif. 2004. 